\title{
Factors Determining the Balance between Online and Face-to-Face Teaching: An Analysis using Actor-Network Theory
}

\author{
Lily Wong and Arthur Tatnall \\ Victoria University, Melbourne, Australia
}

lily.wong@vu.edu.au; arthur.tatnall@vu.edu.au

\begin{abstract}
Many universities, and other higher education institutions, have adopted an approach to teaching and the delivery of course content that combines traditional face-to-face delivery with online teaching resources: a blended learning approach. It does not follow, however, that merely defining a policy in this area will cause the desired result, as first the new ideas have to be adopted by all those involved. Many factors act to determine how online learning is accepted and how the balance between online and face-to-face delivery is formed. This paper investigates the factors that determine the way that online resources have been implemented in a core first-year accounting subject. The approach used is one involving actor-network theory because of the combinations of both human and non-human actors involved. In this paper, the main actors are identified, and we look at how their views of the value of each approach and their willingness to attempt to convince others of the "rightness" of these views affects the outcome.
\end{abstract}

Keywords: blended learning, innovation, introductory accounting, university policy, actornetwork theory.

\section{Introduction}

This paper examines the factors in Victoria University that led to decisions on determining the balance between online and face-to-face teaching in a large first- year business subject. One of Victoria University's key policies has been to use make use of technology, along with traditional face-to-face approaches, in the teaching and learning process in an effort to enhance the quality of the learning experienced by its students. This policy is not unique and the trend toward blended learning is emerging as a prominent method of delivery in higher education (Bonk \& Graham, 2006). This paper describes a research project which documents and examines the introduction of online resources into an introductory core accounting subject.

Victoria University's first-year core accounting subject, BAO-1101: Accounting for Decision Making, is compulsory for all students

Material published as part of this publication, either on-line or in print, is copyrighted by the Informing Science Institute. Permission to make digital or paper copy of part or all of these works for personal or classroom use is granted without fee provided that the copies are not made or distributed for profit or commercial advantage AND that copies 1) bear this notice in full and 2) give the full citation on the first page. It is permissible to abstract these works so long as credit is given. To copy in all other cases or to republish or to post on a server or to redistribute to lists requires specific permission and payment of a fee. Contact Publisher@InformingScience.org to request undertaking a Bachelor of Business degree. With around 1,000 students enrolled in this subject each semester, this is a very diverse group comprising accounting and non-accounting students from a broad spectrum of business degrees, which range from music industry management through to marketing and information systems. 
This cohort of students have had very different experiences in studying accounting, if they have previously studied it at all, and their perceptions about this subject are quite varied. Negative attitudes towards accounting are not unusual among introductory accounting students (Mladenovic, 2000) and earlier studies suggest that changes in accounting education should begin with the very first subject in accounting, as it not only sets the tone, but also provides the foundation for further interest in accounting studies (Mintz \& Cherry, 1993; Wong \& Tatnall, 2009). It is therefore very important that the teaching material used in this subject is designed and developed with an understanding of these differences so that it meets the varying needs of its students.

The learning technology introduced was Blackboard (previously known as WebCT), an online learning platform provided by Blackboard Learning Systems. This educational technology was initially introduced into the first-year accounting subject in 2006, with a basic level of online teaching resources provided to students. Over the following semesters, additional resources have been developed, including video, audio-visual, text, images, and animations to support student learning. As most readers will know, Blackboard offers a number of facilities for the management of e-learning, including: discussion boards, an e-mail system, live chat, and the support of content including documents, spreadsheets, and links to web pages. In the first semester of 2009, recorded lectures were made available to students via Blackboard and online tutorials will be introduced in 2010. Blackboard's communication tools, which include discussion boards and a chat function, enable students to regularly interact with each other, as well as their tutor or lecturer. Various assessment tasks can also be undertaken online and statistical details provided by this learning system enable the monitoring of student performance (Wong \& Tatnall, 2009).

Garrison and Vaughan (2008, pp. 144-145) have identified three major changes that have recently occurred in higher education:

- Unprecedented advances in communication technology

- New challenges within institutions resulting in less contact time with academic staff

- Recognition that traditional methods are unable to address the need for higher-order learning experiences and outcomes demanded by a changing knowledge and communication-based society.

These changes have led to the emergence of blended learning, which according to Bonk and Graham (2006, p. 5) "is part of the ongoing convergence of two archetypal learning environments:" the traditional face-to-face and the computer-mediated learning environment. In the past these had remained quite separate. Bonk and Graham (2006, p. 7) go on to suggest that: "Whilst it is acknowledged that it is impossible to predict what the future holds, there is some certainty that the trend toward blended learning systems will increase".

\section{Socio-Economic Background of the Students}

Some discussion of the background of the students is necessary as it has been acknowledged (Mc Innis, James, \& Mc Naught, 1995) that age, gender, country of birth, language spoken at home, socio-economic background, and ethnicity contribute to shaping student expectations of university study. They also affect their adjustment to being university students and, ultimately, their overall teaching and learning experience (Wong \& Tatnall 2009). The following figures collected over a four year period from 2006 to 2009 from student surveys and the university's student database provides an overview of the students enrolled in this subject.

\section{Gender}

The student population shows an almost equal representation with approximately $50 \%$ of male and $50 \%$ female students enrolled in this subject over the four year period from 2006 to 2009. 


\section{Language Spoken At Home}

The results for language spoken at home show a reversal in trends from 2006 to 2009. In 2006, the most prominent language spoken at home was a language other than English accounting for $40 \%$ of the sample. By 2009 , this gradually declined to $38 \%$. The proportion of students whose first language was English has grown considerably, increasing from $34 \%$ to $55 \%$ over the same period.

\section{Ethnic Origin}

The student population is predominantly Australian born with this number increasing from $68 \%$ to $73 \%$ over the four years. This seems to be consistent with the increase in English speaking students over the same period. The next largest groups are Asian-born students making up 11\%, and European-born students accounting for 5\%.

\section{Study Mode (Part-Time Versus Full-Time)}

The vast majority of students were studying in full-time mode, with only $12 \%$ studying in part-time mode in 2006. Over the four year period, the proportion of full-time students increased slightly from $88 \%$ to $89 \%$.

5. Age

In 2006, the dominant group were those students less than 20 years of age representing $64 \%$. Of the older students, $31 \%$ were from $20-29$ years of age and only $5 \%$ consisted of mature students aged 30 years or older. By 2009, the proportion of younger students showed a marked rise to $73 \%$, with subsequent decreases in the number of students from the other age groups.

\section{Socio-Economic Background}

The largest proportion of students are from a medium socio-economic background accounting for $46 \%$ of the student population in 2006 . This was followed by $34 \%$ of students of a low socio-economic status background and $20 \%$ from one of high socio-economic status. These proportions have remained steady from 2006 to 2009.

\section{ENTER scores}

The Equivalent National Tertiary Entrance Rank (ENTER score) is an overall ranking system used by Australian universities to select students for their courses (Wong \& Tatnall, 2009) and is calculated from the study scores in their final year of secondary education. Generally, a higher ENTER score reflects a higher level of academic achievement and, therefore, preferential in the selection of students into university courses. The data may be interpreted to show that from 2006 onwards at Victoria University there was an increase in the number of students accepted with lower ENTER scores.

\section{Methodology}

This research used a mixed method approach involving interviews, focus groups, questionnaires, and document analysis. It is now partially complete, but with many on-going aspects. To gather the data required, a number of sources were utilised. Information was retrieved from the university's student database to show statistics on student participation rates for online tests accessible through analytical tools on the Blackboard course management system, and academic performance measures calculated from comprehensive records kept on student assessment. Student evaluations for this subject comprised a set of criteria against which the quality of the subject is rated. These cover appropriateness of workload and assessment, quality of teaching materials, ability of the teacher to motivate students, and the relevance of the course content. The final question asks students to provide an overall rating of the quality of the subject on a scale from 1 (Very Poor) to 5 (Very Good). The university makes these evaluations compulsory, and they are required to be formally conducted by an external administrator at the end of each semester. 


\section{Actors, Networks, and Actor-Network Theory (ANT)}

A simple investigation quickly shows that a large number of different entities have an effect on determining how much online and how much face-to-face teaching to include in a university subject like this. Furthermore, not all of these entities, or actors, are human as the technology itself has an important determining effect (Tummons, 2009). Is it easy to use? What functions does it offer? How much does it cost? Other non-human actors include university policy, computer labs and infrastructure.

Actor-Network Theory (ANT) declares that the world is full of hybrid entities (Latour, 1993) containing both human and non-human elements and was developed to analyse situations where separation of these elements is difficult (Callon, 1997, p. 3; Tatnall, 2009a; Tatnall \& Gilding, 1999). It is difficult, for example, to differentiate a computer program's technical aspects from the influence exerted by the socio-cultural background of the software development team (Cusumano \& Selby, 1997; Sahay, 1997). Actor-Network Theory was designed as an approach to socio-technical research that would address the need to treat the contributions of both human and non-human actors fairly and in the same way (Callon, 1986; Latour, 1996; Law, 1991). To do this, ANT is based upon three principles: agnosticism, generalised symmetry, and free association (Callon, 1986), which mean that it attempts impartiality towards all actors in consideration, whether human or non-human, and makes no distinction in approach between the social, the natural and the technological.

Actor-Network Theory, or the "sociology of translations" (Callon, 1986; Law, 1992), is concerned with studying the mechanics of power as this occurs through the construction and maintenance of networks made up of both human and non-human actors. The view of innovation proposed by ANT is known as Innovation Translation (Latour, 1986, 1996; Law \& Callon, 1988) and makes use of a model of technological innovation that uses these ideas, along with the concept that innovations are often not adopted in their entirety, but only after "translation" into a form that is more appropriate for use by the potential adopter (Tatnall, 2009b).

This model of translation proposed in Actor-Network Theory proceeds from a quite different set of assumptions to those used in Innovation Diffusion (Rogers, 2003) or the Technology Acceptance Model (Davis, 1986). Latour (1986) argues that the mere "possession" of power by an actor does not automatically confer the ability to cause change unless other actors can be persuaded to perform the appropriate actions for this to occur. An actor-network is configured (Grint \& Woolgar, 1997) by the enrolment of both human and non-human allies, and this is done by means of a series of negotiations in a process of re-definition in which one set of actors seek to impose definitions of the situation on others (Callon, 1986; Tatnall, 2009a; Tatnall \& Gilding, 1999).

The first step in an actor-network analysis is to identify the actors involved. Law (1987) describes an actor as any human or non-human entity that is able to make its presence individually felt by other actors.

At Victoria University the actors involved in this case include: the Bachelor of Business Course Coordinator, the BAO-1101 Subject Coordinator, Subject Lecturers, Subject Tutors, Sessional (Contract) Tutors, other lecturers, the Faculty Dean and the University Administration, the Head of School of Accounting, University Policy, University Infrastructure, Technical Staff from Information Technology Services, students, computers, screens, computer laboratories, e-learning infrastructure (including remote access), competing technologies, and the Blackboard e-learning environment itself. Each of these actors potentially has an influence on how or whether the adoption occurs and the balance between an online and a face-to-face approach.

Callon, Courtial, Turner, and Bauin (1983) have proposed that translation involves all the strategies that an actor goes through to identify other actors and to work with or against them in order 
to achieve the adoption. Latour (1996) speaks of "chains of translation" and suggests that the innovation moves only if it interests one group of actors or another. Callon (1986) suggests that the process of translation has four aspects or "moments": Problematisation, Interessement, Enrolment, and Mobilisation.

\section{Problematisation}

In this moment of translation the problem is re-defined (translated) in terms of solutions offered by those actors advocating its adoption. The following discussion will look at the problematisations proposed by some of the actors. Getting the views of the human actors just involves talking to them, but not so obvious is the influence of some of the non-human actors ${ }^{1}$.

Firstly consider Blackboard, the e-learning package itself and a non-human actor. Since it was designed with the express purpose of providing an online learning environment, its problematisation of this issue would be that it can provide an efficient means of delivering teaching materials whilst enhancing student accessibility. From this perspective: "Why would you want to use anything else? Why do you need to think about face-to-face teaching at all when Blackboard can do everything you need?" Other non-human actors include the computers, screens, computer laboratories, and internet services. As with Blackboard, these facilities and services were purchased with the purpose of providing appropriate infrastructure for the teaching function, therefore their problematisation is similar to that of Blackboard. Similarly, Information Technology Services, whose responsibility is to manage the computing infrastructure, views it as their duty to make the technology work and not to argue about whether or not it should be used.

Perhaps the most important human actor who has the highest level of interest and commitment to this subject, the actor that Law (1987) calls the "Heterogeneous Engineer," is the BAO-1101 Subject Coordinator. The problematisation proposed by this individual is a simple one: the combination of online and face-to-face teaching must provide the best possible learning experience for the students, whatever that may be. The teaching responsibilities of this large subject are shared between approximately 12 staff, the majority of whom are part-time. Whilst full-time staff are responsible for the lectures, most of the tutorials are taken by part-time staff. This too, is a diverse group, who vary in age, experience and teaching styles. They also share different views of using technology in their teaching, with many of the lecturers and tutors having mixed views on the optimal balance. Some are insistent in retaining as much as possible of the traditional modes of delivery, and others are more willing to experiment with more innovative techniques such as recorded lectures and online tutorials. From the demographic profile, it is noted by 2009 the dominant group are those students less than 20 years of age representing $73 \%$ of the students enrolled in this first year accounting subject. There is much pressure from this section of the student population to incorporate the latest technology to enhance their learning. Recent subject evaluations have shown that student perception of this subject has improved with the increased availability of online teaching resources. At the end of each semester, students are required to evaluate the quality of the subject on a scale from 1 (Very Poor) to 5 (Very Good). Prior to the introduction of WebCT in 2005, students rated this subject at 3.9 compared to 4.05 in 2009 (Wong, 2010).

Their problematisations are therefore also varied.

Colleagues who lecture in subjects other than first year accounting also have their own views on the balance of online versus face-to-face teaching, but the importance of these views depends on how close is their relationship with those teaching BAO-1101. In some cases where the relation-

1 Those readers not used to the concepts of actor-network theory might be surprised at the approach used to give a voice to the non-human actors. This is not intended as an attempt at anthropomorphism, but simply as a method of examining how these actors exert an influence. 
ship and respect is quite close, these views will have a significant effect on the problematisations of the subject lecturers.

With a strong academic and research background in technology and education, the Head of the School of Accounting is very keen for all his teaching staff to incorporate greater use of technology to support learning. His problematisation is one of the value of this approach in contrast to traditional methods. In 2010 it will be compulsory for all major accounting subjects to be conducted in lecture theatres with the facility to record lectures and then to make them available online. The majority of students enrolled in BAO-1101 are from a lower to medium socioeconomic background and are generally working in part-time jobs in addition to studying fulltime. In recognition of this, access to recorded lectures and the introduction of online tutorials will provide more flexible learning options for these students.

The views of the university hierarchy, which in many ways, can be thought of as a "black box" (Callon 1986), are a little harder to ascertain. Obviously if the Vice Chancellor, Faculty Dean, or Course Coordinator expresses a view on this then it must be taken into account, but this much is obvious (Tatnall \& Manning, in press). University policy problematises use of technology as an important tool in delivery of learning, but the extent to which all parts of the university agree with this is unclear.

In many ways, one of the most important actors are the students enrolled in this subject. Does their gender, age, ethnicity, socio-economic background, or part-time or full-time enrolment status affect their views on online versus face-to-face teaching? One can strongly suspect that it does, but this part of the research is still on-going and a definitive answer has yet to be determined. Given the increasing number of students coming into the subject with lower levels of academic ability, initial findings suggest that students have indicated a preference for greater face-toface interaction with their lecturer and tutor (Wong, 2010).

In summary, if some actors feel strongly enough about this matter and have problematised (Callon, 1986) the use of an e-learning environment in their own way, then they will certainly apply pressure to the decision makers and other actors to try to enrol them (Callon, 1986) into making what they consider to be the "right" decision.

\section{Interessement}

This involves "interesting" an entity by coming between it and some other entity (Law, 1986) and attempts to impose identities and roles defined in the problematisation on the other actors (Kasimin \& Ibrahim, 2009; Linden \& Saunders, 2009).

The "Heterogeneous Engineer," being the Subject Coordinator, is perhaps the most important actor at this stage where there is a need to work with the other actors to persuade them to agree to the proposed problematisation. This will involve discussions with the subject lecturers, getting feedback from the students, and working along with university administration to best determine how to make the balance more appropriate between online and traditional methods of subject delivery so that it is conducive to good learning practices.

One problem to overcome here is some aspects of the e-learning package. If it requires too much effort to come to grips with, or the e-learning interface is too off-putting or non-intuitive, then adoption becomes less likely. The designers of the Blackboard have worked over successive versions to offer an interessement here by making the package more intuitive and easier to use. The Heterogeneous Engineer, Subject Lecturers, and Tutors can also offer an interessement to the students by helping them become more familiar with the software. Subject Lecturers, in particular, have been instructed by the Heterogeneous Engineer to demonstrate the various functions of 
Blackboard during their teaching sessions so that students can maximise the benefits available from using this e-learning package.

\section{Enrolment}

All going well, enrolment should then follow through a process of "coercion, seduction, or consent" (Grint \& Woolgar, 1997) leading to the establishment of a solid, stable network of alliances. Exactly what enrolment should be called is questionable when talking about a balance between two approaches. We will say that the actors are enrolled when the "optimum" balance, whatever that might be, between online and face-to-face teaching has been reached.

Even if all the actors are enrolled and the e-learning package is adopted, what if only some aspects of this package are used? How can partial adoption be explained? The less than friendly interface of WebCT has, in the past, been one reason for this, and there are other alternatives to the e-mail function it offers. The in-built testing / marking facilities are of interest to some academics but not to others, so these may or may not be adopted as they will fit less well with their problematisation of what an e-learning environment should be about. On a human level, there seems to be a preference for human to human interaction and reluctance to use technology in this way for teaching and learning. Consequently, with the availability of recorded lectures, there is also the concern that students will no longer bother attending lectures. All of this means that many academics will translate the e-learning package into something that suits their own needs (Tatnall \& Manning, in press).

Research on student motivation by de Lange, Suwardy, and Mavondo (2003) identified that "the challenge for educators is to develop strategies that ensure any novelty effect does not wear off with an end result of technology impeding learning." As a compulsory first-year subject, there is continual pressure on the Heterogeneous Engineer / Subject Coordinator to keep abreast of the latest technological advancements and to incorporate these where possible to enhance the student learning experience. It was heartening to find that there appeared to be some link with the time spent on Blackboard and improvements in academic performance. On average, High Distinction students with final grades of 80 and above logged into 61 sessions and spent an 15 hours engaging with the online resources, whereas failed "N1" students with final grades of 40 to 49 , logged into only 36 sessions and spent 11 hours on Blackboard during the semester (Wong, 2010).

\section{Mobilisation}

Finally, mobilisation occurs as the proposed solution gains wider acceptance and an even larger network of absent entities is created through some actors acting as spokespersons for others (Callon, 1986). It will be clear that a consensus has been reached and that the optimum balance between online and traditional approaches to teaching and learning has been achieved.

\section{Conclusion}

Actor-Network Theory provides a powerful, but somewhat different framework for understanding technological innovation. In refusing to accept the social / technical divide, and by treating human and non-human actors impartially, it avoids the essentialism, lack of heterogeneity, and explanation by use of binaries that are inherent in many other methodologies (Tatnall \& Gilding, 1999). Innovation translation offers an approach to explaining innovation that does not rely on any supposedly innate nature of the innovation, or specific characteristics of the change agents or society, but rather on a process of network formation in which all actors seek to persuade others to become their allies in promoting the acceptance of their own view of the way the problem can best be solved (Tatnall, 2009b). 
One of the issues brought out by an Actor-Network Theory investigation is the effect that force of personality and presence has in a teaching and learning environment and how this might contrast with the effect of the technology. It is clear that the level and quality of interaction between student and lecturer may have a significant impact on student learning and satisfaction. Feedback from a recent student survey conducted on the use of technology used in this first-year accounting subject seems to support this. Many students believe that the personal interaction added value to their learning experience (Wong, 2010), but we will have a better idea of this after completion of the next stage of the research involving student and focus group interviews.

Rebele (2002) has highlighted the importance of research specific to the effective use of technology in accounting education, and Marriott and Lau (2008) note that the paucity of research in this area is still evident. Therefore, with the increasing prominence of blended learning in higher education (Bonk \& Graham 2006), the need for research in this area has become even more important.

\section{References}

Bonk, C. J., \& Graham, C. R. (2006). The handbook of blended learning - Global perspectives, local designs. CA: Pfeiffer, Wiley imprint.

Callon, M. (1986). Some elements of a sociology of translation: Domestication of the scallops and the fishermen of St Brieuc Bay. In J. Law, Power, action \& belief. A new sociology of knowledge? (pp. 196-229). London: Routledge \& Kegan Paul.

Callon, M. (1997). Actor-network theory - The market test (draft). Actor Network and After Workshop, 31 July 1997, Centre for Social Theory and Technology (CSTT), Keele University, UK. Retrieved from http://www.keele.ac.uk/depts/stt/stt/ant/callon.htm

Callon, M., Courtial, J. P., Turner, W. A. \& Bauin, S. (1983). From translations to problematic networks: An introduction to co-word analysis. Social Science Information, 22(2), 191-235.

Cusumano, M. A., \& Selby, R. W. (1997). How Microsoft builds software. Communications of the ACM, 40(6), 53-61.

Davis, F. D. (1986). A technology acceptance model for empirically testing new end-user information systems: Theory and results. Doctoral dissertation. Sloan School of Management, MIT, Boston.

de Lange, P., Suwardy, T., \& Mavondo, F. (2003). Integrating a virtual learning environment into an introductory accounting course: Determinants of student motivation. Accounting Education, 12(1), 1 14.

Garrison, D. R., \& Vaughan, N. D. (2008). Blended learning in higher education - Framework, principles and guidelines. CA: Jossey-Bass, Wiley Imprint.

Grint, K., \& Woolgar, S. (1997). The machine at work - Technology, work and organisation. Cambridge: Polity Press.

Kasimin, H., \& Ibrahim, H. (2009). Exploring multi-organizational interaction issues: A case study of information technology transfer in the public sector of Malaysia. International Journal of ActorNetwork Theory and Technological Innovation, 1(3), 70-83.

Latour, B. (1986). The powers of association. In J. Law, Power, action and belief. A new sociology of knowledge? Sociological review monograph 32 (pp. 264-280). London: Routledge \& Kegan Paul.

Latour, B. (1993). We have never been modern. Hemel Hempstead, Harvester Wheatsheaf.

Latour, B. (1996). Aramis or the love of technology. Cambridge, MA: Harvard University Press.

Law, J. (1986). The heterogeneity of texts. In M. Callon, J. Law, \& A. Rip, Mapping the dynamics of science and technology (67-83). UK: Macmillan Press. 
Law, J. (1987). Technology and heterogeneous engineering: The case of Portuguese expansion. In W. E. Bijker, T. P. Hughes, \& T. J. Pinch, The social construction of technological systems: New directions in the sociology and history of technology (pp. 111-134). Cambridge, MA: MIT Press.

Law, J., (Ed.). (1991). A sociology of monsters. Essays on power, technology and domination. London: Routledge.

Law, J. (1992). Notes on the theory of the actor-network: Ordering, strategy and heterogeneity. Systems Practice, 5(4), 379-393.

Law, J., \& Callon, M. (1988). Engineering and sociology in a military aircraft project: A network analysis of technological change. Social Problems, 35(3), 284-297.

Linden, L., \& Saunders, C. (2009). Linux kernel developers embracing authors embracing licenses. International Journal of Actor-Network Theory and Technological Innovation, 1(3), 15-35.

Marriott, P., \& Lau, A. (2008). The use of on-line summative assessment in an undergraduate financial accounting course. Journal of Accounting Education, 26(2), 73-90.

Mc Innis, C., James, R., \& Mc Naught,C. (1995). First year on campus - Diversity in the initial experience of australian undergraduates. Melbourne: Centre for the Study of Higher Education,University of Melbourne.

Mintz, S., \& Cherry, A. A. (1993). The introductory accounting courses: Educating majors and nonmajors. Journal of Education for Business, 68(5), 276-280.

Mladenovic, R. (2000). An investigation into ways of challenging introductory accounting student's negative perceptions of accounting. Accounting Education, 9(2), 135-155.

Rebele, J. E. (2002). Accounting education's uncertain environments: Descriptions and implications for accounting programmes and accounting education research. Accounting Education, 11(1), 3-25.

Rogers, E. M. (2003). Diffusion of innovations. New York: The Free Press.

Sahay, S. (1997). Implementation of information technology: A space-time perspective. Organization Studies, 18(2), 229-260.

Tatnall, A. (2009a). Information systems, technology adoption and innovation translation. International Journal of Actor-Network Theory and Technological Innovation, 1(1), 59-74.

Tatnall, A. (2009b). Innovation translation as a research approach to theorising information systems implementation. International Journal of Networking and Virtual Organisations, 6(1), 64-76.

Tatnall, A., \& Gilding, A. (1999). Actor-network theory and information systems research. 10th Australasian Conference on Information Systems (ACIS), Wellington, Victoria University of Wellington.

Tatnall, A., \& Manning, K. (in press). Innovation or renovation? The management of strategic and adoption decisions within a university. In A.Tatnall, A. J. Visscher, \& O. C. Kereteletswe, Information technology and the management of quality education. Heidelberg: Springer.

Tummons, J. (2009). Higher education in further education in England: An actor-network ethnography. International Journal of Actor-Network Theory and Technological Innovation, 1(3), 55-69.

Wong, L. (2010). The e-learning experience - Its impact on student engagement and learning outcomes. Business \& Economics Society International Conference. Bahamas.

Wong, L., \& Tatnall, A. (2009). The need to balance the blend: Online versus face-to-face teaching in an introductory accounting subject. Journal of Issues in Informing Science and Information Technology (IISIT), 6, 309-322. Retrieved from http://iisit.org/Vol6/IISITv6p309-322Wong611.pdf 


\section{Biographies}
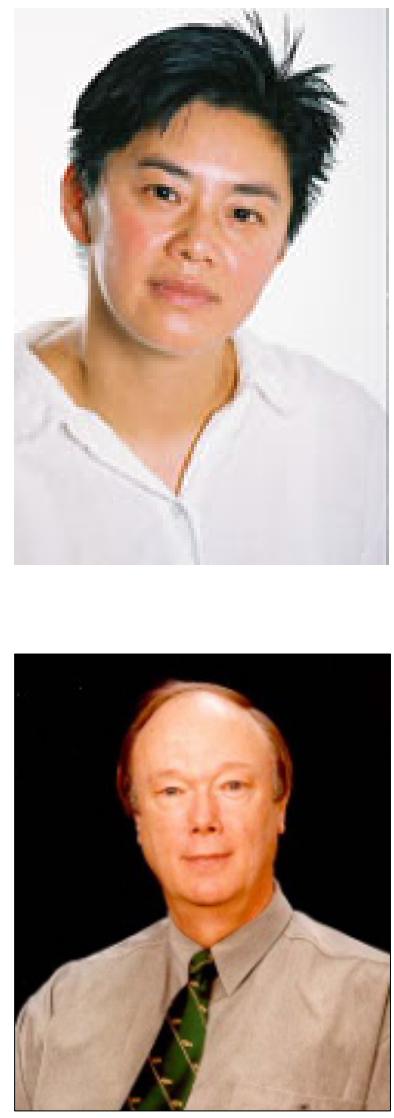

Arthur Tatnall is an Associate Professor in the Graduate School of Business at Victoria University in Melbourne, Australia. He holds degrees in Science, Education and Computer Science. He has a research Master of Arts in which he explored the origins of Information Systems curriculum in Australian universities. His PhD involved a sociotechnical study in curriculum innovation in which he investigated the manner in which Visual Basic entered the curriculum of an Australian university. His research interests include technological innovation, history of technology, information systems curriculum, project management, electronic commerce, and information technology in educational management. He is Editor-in-Chief of the International Journal of Actor-Network Theory and Technological Innovation, the Journal of Education and Information Technologies and the Journal of Business Systems, Governance and Ethics. 